\title{
Perceived Effect of Fuelwood Utilization on Climate Change by Rural Dwellers in Northwestern Nigeria
}

\author{
Comfort Oyekale Adamu ${ }^{1}$ and Cornelius Idowu Alarima ${ }^{2 *}$ \\ ${ }^{I}$ Department of Agricultural Extension and Rural Development, University of Agriculture, Abeokuta, Nigeria \\ ${ }^{2}$ Faculty of Life and Environmental Sciences, Shimane University, Matsue, Japan
}

\begin{abstract}
Creating awareness among people especially rural dwellers in Nigeria about appropriate activities required in terms of mitigating climate change is imperative. This paper discusses climate change in relation to its causes and the perceived effect of fuelwood utilization by rural dwellers in Kebbi, Sokoto and Zamfara states. The study used data from 360 rural people proportionately selected according to the number of agricultural cells of each of the states by simple random sampling. Regression analysis was used to determine the relationship between study variables. Results show respondents age ranged between 20 and 80 years, with a mean of 36.73. They had Quranic education, seasonal contact with extension agents and low awareness of perceived environmental effect of fuelwood utilization. In addition, the study revealed that there is significant relationship between the perceived environmental effect of fuelwood acquisition and age $(\beta=-0.159 ; p<0.01)$, educational level $(\beta=0.461 ; p<0.01)$, contact with extension $(\beta=0.249 ; p<0.01)$ and awareness $(\beta=0.481 ; p<0.01)$. These findings suggest the need for environmental education and consciousness. The study then concludes that agricultural extension programmes in rural communities must be made effective in enlightening the people about environmental consequences of fuelwood utilization and its implication on climate change. The implication of the study is that the higher the level of contact of rural dwellers with extension agents, the higher their awareness of the effect of fuelwood utilization. It also implied that the higher the level of awareness of the rural dwellers the higher their perception of the effect of fuelwood utilization on the environment.
\end{abstract}

Keywords: Fuelwood utilization, rural people, climate change, northwestern, Nigeria

\section{Introduction}

Global attention is being drawn to the issue of climate change as an environmental problem threatening the survival of the entire human race. According to NEST (2004), every part of the earth will be affected by climate change but the degree to which such impact will produce damage will differ depending on demographic circumstances, capacity to withstand the impact and the nature of the economy. The report noted that developing countries will be the most vulnerable to the impact of climate change. Supporting this view, IPCC (2007) and Okali (2004) explained that developing countries will be the most vulnerable because their economies are based largely on natural resources that are dependent on climate change. Renewable natural resources are resources which can restock themselves and be used indefinitely if they are used sustainably. That is, the rate of the resources and stock capacity of the resource (Ancha et al., 2008). Renewable resources include animals, soil, plants, water, solar and wind energy.

\footnotetext{
${ }^{*}$ Corresponding author.
}

Recent studies have shown remarkable changes in availability, fluctuation rates and redistribution of renewable natural resources (Draggan, 2007). These changes have been attributed to climate change. That is, these resources especially crops and solar energy have changed. Climate change refers to any change in climate overtime, either due to natural variability or as a result of human activity (IPCC, 2007; Fusel, 2007).

The changes occur due to variation in different climatic parameters such as cloud cover, precipitation, temperature and increase in Green House Gases (GHG's) emission through human activities. Climate change is predicted to have the main impact on agriculture, economy and livelihood of the populations of under-developed world (Kandji et al., 2006). Adverse impacts of climate change in Nigeria and other developing nations include frequent drought, increased rural-urban migration, increased biodiversity loss, depletion of wild and other natural resource base, changes in vegetation types, increased health risk and the spread of infectious diseases and changing livelihood systems (Abaje \& Giwa, 2007; Hassan \& Hemachena, 2008). 
There has been dwindling crop harvests, high solar radiation and changes in crop seasons during rainfall fluctuations. To overcome the problem of climate change, especially in Nigeria, there is need to assess the awareness and perception of the people about it. An understanding on global climate and its change is pre-requisite to taking appropriate initiatives to combat climate change. Tackling the challenges of climate change to rural dwellers who are mostly farmers will require a thorough knowledge of the people's perception on climate change and factors affecting their perception of climate change especially as related to fuelwood use. Majority of the rural dwellers in Nigeria depend on fuelwood as their main source of household or domestic energy. Information available showed that little is known about climate change in the study area. As reported by previous authors, a number of factors influence perception of climate change which includes education, experience and access to extension services. Ability to perceive climate change is a key precondition for their choice to adapt. Hence, this paper highlights awareness and perception of fuelwood utilization on climate change. The main objective of the study was to examine respondent's perception of effect of fuelwood utilization on climate change. The specific objectives of the study are to assess the awareness level of climatic change, identify some documented causes of climate change, describe some activities that can help to mitigate the effect of climate change, identify the role of extension contact in respondents' perception of effect of fuelwood utilization on climate change and investigate the perceived effect of firewood utilization on climate change by rural dwellers.

\section{Methodology}

\section{Sampling and data collection}

The survey research design and focused group discussion was used for this study. Sampling frame consisted of 256, 128 and 224 cells of Kebbi, Sokoto and Zamfara states respectively. Simple random sampling procedure was used to select 360 rural communities from each of Kebbi, Sokoto and Zamfara states in proportion to the number of cells they have. Therefore 156, 72 and 132 respondents were chosen. These dwellers were interviewed using a structured interview guide. Data for the study were collected using face-to-face interviews with the assistant of extension agents in the study locations. This study was carried out in 2009. Data collected include personal characteristics, level of extension contract and perceived effect of fuelwood utilization.

\section{Validity and reliability}

The structured interview guide was subjected to face and content validity with the help of resource persons in agricultural extension. This was done in order to ensure that the study variables were appropriately and adequately captured and measured. The reliability of the data gathering instrument was conducted using test-re-test method. To this end, the structured interview guide was administered to 36 respondents (10\% of the sample for the study) randomly selected from the study population at interval of two weeks after which the responses were compared. Items that were readily responded to were ascertained okay while the ones that were too technical or ambiguous were modified to ensure the reliability and standardization of the structured interview guide. Using Pearson Product Moment Correlation analysis, the results of the data collected at interval of two weeks were analyzed. A correlation coefficient of $r=0.87$ was obtained.

\section{Variable selection and measures}

\section{Dependent variable}

The dependent variable for this study is perceived effect of fuelwood utilization on the environment. This is determined by developing perception statements on a four point likert scale. This was defined on a 4-point likert scale of strongly agree $(\mathrm{SA}=4)$ agree $(\mathrm{A}=3),(\mathrm{D}=2)$ and strongly disagree $(\mathrm{SD}=1)$ following Alarima (2011) and Mustapha et al. (2012). Scale scores were computed by summing across responses to items in the scale. Ten perception statements were developed to capture effect of climatic change on rainfall pattern, temperature change, green house effect, timing of rainfall, variations in agricultural seasons and crop and animal production in relation to climate change.

\section{Explanatory variables}

The following are the explanatory variables that are hypothesized to influence perceived effect of fuelwood utilization on the environment in the study area. These variables ranged from age, sex, marital status, educational level, farm size, household size and contact with extension.

Age: This was measured in years as a continuous variable.

Sex: Sex was determined by whether the farmer is a male or female.

Marital status: The marital status of the farmers was measured as either married or single. It is measure at nominal level of measurement.

Religion: This was measured as Christianity or Islam. Educational Level: This measures the level of 
education of the farmer. This was measured ordinally as: no formal education, primary education, secondary education, and Tertiary education.

Household Size: This measures the size of the family. Household size was determined by the actual number of persons in a household.

Major occupation: This was measured as nominal variable as farming (1), trading (2), govt worker (3) and dependant (4).

Awareness: This was measured as Yes (1) for aware and No (0) for not aware.

Contact with Extension Agents: This is measured on a four point likert scale. This was defined on a 4-point likert scale of Very often (fortnightly) $(\mathrm{VO}=4)$, Often $(\mathrm{O}=3)$, Seasonally $(\mathrm{S}=2)$ and None at all $(\mathrm{NO}=1)$.

\section{Data analysis}

Data was subjected to descriptive analysis using frequency counts and percentages while multiple regression analysis was used to establish a relationship between perceived environmental effect and other independent variables as represented in the equation below:

$\mathrm{Y}=\mathrm{a}+\boldsymbol{\beta} \mathrm{X}_{1}+\boldsymbol{\beta} \mathrm{X}_{2}+\boldsymbol{\beta} \mathrm{X}_{3}+\boldsymbol{\beta} \mathrm{X}_{4}+\boldsymbol{\beta}$ $\mathrm{X}_{5}+\boldsymbol{\beta} \mathrm{X}_{6}+\boldsymbol{\beta} \mathrm{X}_{7}+\boldsymbol{\beta} \mathrm{X}_{8}$

Where

$\mathrm{Y}=$ Perception

$\mathrm{X}_{1}=$ Age

$\mathrm{X}_{2}=$ Sex

$\mathrm{X}_{3}=$ Religion

$\mathrm{X}_{4}=$ Educational Level

$\mathrm{X}_{5}=$ Household size

$\mathrm{X}_{6}=$ Contact with Extension Agents

$\mathrm{X}_{7}=$ Occupation

$\mathrm{X}_{8}=$ Awareness

\section{Results and Discussion}

\section{Respondents' characteristics}

As revealed in Table 1 respondents age ranged between 20 and 80 years, with a mean of 36.73. The large dispersion in age implies that the young, middle aged and the old are represented in rural households. The result also showed that majority of the respondents are married. Majority of the respondents had Quranic education while a little percentage had formal education. The educational make up of the people also indicates that for effective communication or extension service delivery, information should be along indigenous practices drawn from people's experiences. For instance, Umar et al., (2008) suggested a user driven Advisory Extension model. In this model, inter-disciplinary and new partnerships work together to bring innovations to people based on their experiences. Majority of the respondents belong to the Islamic religion. Although the role of religion in perception is divergent, Verdurme and Viaene (2003) believed that religion plays a vital role in influencing perception while Mustapha et al (2012) and Ofuoku (2011) believed otherwise. The result of the study also revealed that family size of the respondents ranged between 1 and 17 persons with an average of 11 persons. This shows a large family size which could be negatively affected in case of any adverse climate change. The major occupation of the respondents is farming. As defined by Ekong (2003), rural is an area of settlement in which half or more than half of the population is engaged in farming. People living in the rural settlement are regarded as rural dwellers who are mostly farmers.

Table 1. Description of the variables of the study.

\begin{tabular}{|c|c|c|c|c|c|}
\hline Acronym & Description & Measurement & Min & Max & Mean \\
\hline \multicolumn{6}{|c|}{ Dependent Variable } \\
\hline PECPT & Perception & $\begin{array}{l}\text { 4-point likert scale of strongly agree }(S A=4) \text { agree }(A=3) \text {, } \\
\text { disagree }(D=2) \text { and strongly disagree }(S D=1)\end{array}$ & 13.00 & 34.00 & 26.28 \\
\hline \multicolumn{6}{|c|}{ Independent Variables } \\
\hline AGG & Age & Continuous variable in years & 20 & 82 & 36.73 \\
\hline MART & Marital status & Nominal: Single (1) Married (2), Divorced (3) Widowed (4) & \multicolumn{3}{|c|}{ Mostly Married } \\
\hline RELG & Religion & Christianity (1) Islam (2) & \multicolumn{3}{|c|}{ Mostly Islam } \\
\hline EDD & $\begin{array}{l}\text { Educational } \\
\text { Level }\end{array}$ & $\begin{array}{l}\text { No formal education (1), Adult education (2), Quranic } \\
\text { education (3), Primary school (4) Secondary School (5) and } \\
\text { Tertiary education (6). }\end{array}$ & \multicolumn{3}{|c|}{ Mostly Quranic education } \\
\hline HHSIZ & Household size & Number of persons in the household & 1 & 17 & 11 \\
\hline OCCP & Major occupation & Farming (1), Trading (2), Govt worker (3), Dependant (4). & \multicolumn{3}{|c|}{ Mostly farming } \\
\hline EXTN & $\begin{array}{l}\text { Contact with } \\
\text { Extension Agents }\end{array}$ & $\begin{array}{l}\text { Very often (fortnightly) }(\mathrm{VO}=4) \text {, Often }(\mathrm{O}=3) \text {, Seasonally } \\
(\mathrm{S}=2) \text { and None at all }(\mathrm{NO}=1) \text {. }\end{array}$ & \multicolumn{3}{|c|}{ Mostly Seasonally } \\
\hline AWAR & Awareness & Dummy ( 1 if yes, 0 if no) & 0 & 1 & 0.48 \\
\hline
\end{tabular}




\section{Extent of contact with extension personnel}

As shown in Table 1, majority of the respondents come in contact with extension personnel only seasonally. However, few of the rural farmers do not have contact with extension personnel at all. Most often, rural farmers avail themselves of extension agents' visits just before the planting season. It is during this period that the extension agents go to the rural farmers with agricultural inputs such as improved seeds, fertilizers and various tractor hiring services. The inadequacy of these seasonal contacts is apparent and hence the advocacy of advisory extension practice. In this case, extension personnel through informal interactions with rural farmers get them interested in practices that are often discussed.

\section{Awareness of climate change}

The result of the study showed that the awareness of climate change among the respondent is low with an average of 0.48 . This shows that majority of the respondents are not aware or have not heard about climate change. Awareness as reported by Alarima (2011) is a critical determinant of perception. With low awareness, understanding of climate change and its effect on the health of the respondents, crops, animals and on the environment in general will be a difficult task to achieve.

\section{Causes of climate change}

Climate change is the long term change in regions weather events (UNEP, 2005). It has also been defined by the United Nations Framework Convention on climate change as a change of climate that is attributed directly or indirectly to human activity that alters the composition of global atmosphere and which in addition to natural variability is observed over a comparable time period (Greenlane, 2008). Climate change is attracting global concern as a result of its perceived threats to the earth, environment and humanity. According to Aluko et al (2008), climate changes over any particular place on the globe are caused by a host of interacting natural and man-made factors such as solar output, earth-sun geometry and interstellar dust all of which are extra terrestrial in nature. However, internal factors, many of which are open to the influence of man include the land systems (comprising the latitudes, elevation, topography and vegetation), the atmosphere comprising its composition and prevailing winds and the oceans along with their associated currents. Over the past 30 years, researchers have gathered evidence to show that the major change in climate is due to greenhouse gas emissions GHG (Akinbami et al, 2003).
Greenhouse gases are groups of naturally occurring gases that can trap heat near the earth's surface (Phillip \& William, 2004). The major greenhouse gases are water vapor which causes $36-70 \%$ of the greenhouse effect, carbon dioxide $\left(\mathrm{CO}_{2}\right)$ which causes $9-26 \%$, Methane $\left(\mathrm{CH}_{4}\right)$ which causes $4-9 \%$ and Ozone which causes $3-7 \%$ as well as a number of man-made ones such as sulphur hexafluoride $\left(\mathrm{SF}_{6}\right)$, fluorocarbons and hydro fluorocarbons (HFCs) (Phillip \& William, 2004)

In Nigeria, climate change has been attributed to the oil and gas sector, especially in the Niger-Delta and offshore as a result of gas flaring, deforestation through tree cutting, firewood and expanding slash and burn agriculture as well as developmental projects (Pelemo \& Olatoye, 2008). Other areas that contributed to climate change are exhaust from cars and trucks, generators and some similar exhaustive machines. Deforestation and land clearing activities emit about 1.7billion metric tons of carbon per year into the atmosphere (CBD, 2007). Also, about 266 million $\mathrm{kg}$ of firewood is consumed daily (The Guardian 2008). According to Steinfeld et al (2006), livestock is responsible for $18 \%$ of the world's greenhouse gas emission as measured in $\mathrm{CO}_{2}$ equivalents. This includes land use change, through deforestation so as to create grazing land. In addition to $\mathrm{CO}_{2}$ emissions, livestock produces $65 \%$ of human induced nitrous oxide (which has 23 times the global warming potential of $\mathrm{CO}_{2}$ and $37 \%$ of human induced methane).

These activities lead to an increase in the carbon content in the atmosphere. Thus, accumulation of $\mathrm{CO}_{2}$ alongside other trace gases such as methane and nitrous oxide also enhances the greenhouse gases effects and climate change. Research findings of the Intergovernmental panel on climate change (IPCC) confirmed that human activities are warming the earth and causing climate change.

\section{Mitigation of climate change}

Mitigation presently focuses on measures to be taken to reduce the $\mathrm{CO}_{2}$ levels due to emissions from fuel combustion and other human activities. Hence, mitigation through carbon sequestration is being advocated. Carbon sequestration is a natural or artificial process whereby carbon is absorbed by trees to reduce its hazardous effects on the environment. Forest and oceans are known to act as sinks for carbon dioxide. Trees act as a kind environmental 'buffer' for ecosystem they dominate. They help ameliorate the extremes of climate (heat, cold and wind) and create an environment where large land mammals including people can live comfortably. Combating climate change requires concerted action by the global community. However, there is a need for local action to complement the global effort. It is 
to this effect that a survey of the perceived environmental effect of firewood utilization by rural dwellers in Northwestern Nigeria was carried out.

\section{Perceived effect of fuelwood utilization on the environment}

The scale scores ranged between 13.00 and 34.00 with a mean of 26.28. Table 1 revealed that most of the respondents had low perception of the effect of fuelwood utilization on the environment. They saw their fuelwood utilization as having little or no effect on the environment. This data points to the fact that the respondents were unaware of the effect of fuelwood burning on the environment. They were unaware of any gaseous emissions into the atmosphere from their activities. Honourable Izinche Ubaine, Chairman House Committee on climate change in a report on the NTA network on Friday, $10^{\text {th }}$ march 2010 expressed the low level of awareness of Nigerians to climate change.

\section{Regression between perception and predictor variable}

Table 2 revealed an $\mathrm{R}^{2}$ value of 0.66 for the respondents. This simply implies that $66 \%$ of the variations in the perception of the effect of fuelwood utilization on the environment were explained by the predictor variables included in the regression model. The result showed that there is a negative significant relationship between age and perception of the effect of fuelwood utilization on the environment. This suggests that the probability of perception of the effect of fuelwood utilization on the environment is higher among the young people than older ones. The result showed that that there is a positive significant relationship between educational level of respondents and perception of the effect of fuelwood utilization on the environment. The implication of this is that, the higher the level of education, the higher the perception of the effect of fuelwood utilization on the environment. The result of the study further showed that there is a positive significant relationship between respondents' contact extension agents and perception of the effect of fuelwood utilization on the environment. This implies that the higher the contact with extension agents, the higher the perception of the effect of fuelwood utilization on the environment. Since extension agents provide information and technical advice to the farmers, their role in perception of the effect of fuelwood utilization on the environment cannot be overlooked. Most of the rural dwellers are farmers and extension agents tend to bridge the gap of access to information. The information available is a critical factor in influencing perception. Napier et al. (2004) reported that exposure to information affects peoples' orientation and perception. The efficiencies in the development and delivery of relevant information and assistance from extension systems determine to a greater extent the perception of rural people. Agricultural extension agents play a significant role in extension services (Tladi, 2004). The success or failure of any environmental awareness campaign programme is dependent on effective performance of extension agents who are close to the people. The result further showed that there is a positive significant relationship between respondents' awareness and perception of the effect of fuelwood utilization on the environment. This implies that the higher the level of awareness, the higher the perception of the effect of fuelwood utilization on the environment. The results revealed that higher awareness will lead to higher perception among the respondents. This study has revealed that there is a need for more environmental education among the rural dwellers as to the fact that their fuel wood utilization has great influence on the environment. This can only be done through more extension contact with the people. Extension practices in form of homestead tree-planting and agro-forestry must be encouraged alongside other farming practices being brought to them.

Table 2. Regression between perception and predictor variable.

\begin{tabular}{lcccl}
\hline Variables & Standardised Coefficients $(\beta)$ & S.E. & t-ratio (B/S.E.) & Sig \\
\hline AGG** & -0.159 & 0.021 & -2.850 & 0.005 \\
MART & -0.109 & 0.028 & -1.816 & 0.071 \\
RELG & -0.005 & 0.017 & -0.088 & 0.930 \\
EDD** & 0.461 & 0.259 & 9.296 & 0.000 \\
HHSIZ & 0.018 & 0.021 & 0.349 & 0.728 \\
OCCP & 0.080 & 0.015 & 1.405 & 0.162 \\
EXTN** & 0.249 & 0.196 & 4.818 & 0.000 \\
AWAR** & 0.481 & 0.242 & 9.408 & 0.000 \\
Constant & & 1.433 & 4.983 & 0.000 \\
\hline
\end{tabular}

$\mathrm{R}=0 . .81 ; \mathrm{R}$ Square $=0.66 ;$ Adjusted. $\mathrm{R}$ Square $=0.64 ; \mathrm{F}$ value $=35.10 ;$ Sig. $=0.00$

$* *$ : significant at $\mathrm{P}<0.01$ 


\section{Conclusion and Recommendation}

This study affirms that rural people are yet to be availed with relevant environmental education tailored towards mitigating the effects of climate change. There is a need for individual as well as collective action in this regard. Education, information and awareness creation among Nigerians should be used by government for creating the consciousness required by individuals to either combat or adapt to climate change. Effective agricultural extension practices should be used in bridging efforts of all stakeholders in environmental management. The implication of this study is that effort at creating should be targeted at the young and educated members of the communities who can help create more awareness among the people. It also implied that the role of extension agents should be exploited as part of effort to mitigate adverse effect of climate change in the study area. The implication of this study is that implications of the study were that the higher the level of contact of rural dwellers with extension agents, the higher their awareness of the effect of fuelwood utilization. It also implied that the higher the level of awareness of the rural dwellers the higher their perception of the effect of fuelwood utilization on the environment.

\section{References}

Abaje, I.B. \& P.N. Giwa. (2007). Urban flooding and environmental safety: a case study of Kafanchan in Kaduna State, Nigeria. A paper presented at the golden jubilee(50th anniversary) and 49th annual conference of the Association of Nigerian Geographers(ANG) at the university of Abuja,15th -19th October

Akinbami, J.F.K., A.T. Salami \& W.O. Siyanbola (2003). An integrated strategy for sustainable forest-energy- environment interaction in Nigeria. Journal of Environmental Management, 69 (2), 115 - 128.

Alarima, C.I. (2011). Knowledge and perception of genetically modified foods among agricultural scientists in south-west Nigeria. OIDA International Journal of Sustainable Development. 2 (6), 77-88.

Aluko, A.P, B . Oyeleye, O.N. Sulaiman \& I.E. Ukpe (2008). Climate change: A threat to food security and environmental protection. In climate change and sustainable renewable natural resources management. Proceedings of the $32^{\text {nd }}$ Annual Conference of the Forestry Association of Nigeria (Ed) L. Popoola pp35-43.

Ancha, P.U. N.T. Tee \& E.T. Tembe (2008). Effects of climate change on renewable natural resources management. In proceedings of $32^{\text {nd }}$ Annual Conference of the forestry Association of Nigeria (Ed) L. Popoola pp $282-287$.

CBD, (2007). Biodiversity and climate change. Booklet prepared for international day for Biological Diversity 2007 Convention on Biological Diversity: Environment 7(6), 9.
Draggan, S. (2007). Renewable resource use and climate change in the Artic. International Arctic Science Committee. Retrieved from: http://www.eoearth.org/article/Renewable_resource_ use_and_climate_change_in_the_arctic

Ekong, E.E. (2003). Introduction to rural sociology. Done Educational Publishers, Uyo, Nigeria.

Fusel, H. (2007). Vulnerability: A generally applicable conceptual framework for climate change research. Global Environmental Change, 17(2), 155-167.

Greenlane, (2008). What is climate change? Greenlane website Retrieved from: http://www.climatechange.org

Hassan, R. \& C. Nhemachena (2008). Determinants of African farmers' strategies for adapting to climate change: Multinomial choice analysis. African Journal of Agriculture and Resource Economics, 2(1), 83-104.

IPCC, (2007). Climate change: Impacts, adaptation and vulnerability. Working Group II Contribution to the IPCC Fourth Assessment Report.

Kandji, S.T., L. Verchot \& J. Mackensen (2006). Climate change and variability in the Sahel region: impact and adaptation strategies in the agricultural sector. ICRAF-UNEP

Mustapha, S.B, A.H. Sanda \& H. Shehu (2012). Farmers' perception of climate change in central agricultural zone of Borno State, Nigeria. Journal of Environment and Earth Science, 2 (11), 21-27.

Napeir, T.L., M A.Tucker, C. Henry \& X. Yang (2004). Ethical orientation of Ohio residents towards genetically engineered plants and animals. An urban/rural comparison. Journal of Food, Agriculture and Environment, 2, 400 -411

NEST (2004). Nigeria Climate Executive Summary of five multisector surveys on Nigeria's vulnerability and adaptation to climate change. A joint project of NEST and GCCI, Canada under the auspices of Canada - Nigeria Climate Change capacity development project. NEST Publication Ibadan pp 16

Ofuoku, A.O. (2011). Rural farmers' perception of climate change in central agricultural zone of Delta State, Nigeria. Indonesian Journal of Agricultural Science, 12(2), 63-69.

Okali D.U. (2004). Climate change and Nigeria. A guide for policy makers. A joint project of NEST and GCSI, NEST Publications, Ibadan pp20.

Palemo, O.J. \& T.O. Olatoye (2008). Causes and implications of climate change in Nigeria. Proceedings of the $32^{\text {nd }}$ Annual Conference of the Forestry Association of Nigeria (Ed) L. Popoola pp 197 - 201

Philip, M.F. \& F.L. Williams (2004). Tropical deforestation and greenhouse gas emissions. Ecological Applications, 14(4), $982-986$

Steinfeld, H, T. Gerber, V. Wassenaar, M. Castel \& C.D. Rosales (2006). Livestock's Shadow. United Nations Report.

The Guardian, Newspaper Nigeria, Friday April 18, 2008.

Tladi F.M. (2004). Job content and training needs of agricultural extension agents in south- central. Botswana Journal of International Agricultural Extension Education, 11(3), 33-39.

Umar A.G., B.O. Omoayena \& M.C. Okonkwo (2008). The Climate - change scouge and implications for national food security in Nigeria: Issues and challenges for extension services delivery. Proceedings of the $32^{\text {nd }}$ Annual Conference of the Forestry Association of Nigeria (Ed) L. Popoola. pp 29-34.

United Nations Environmental Programme (UNEP) (2005). Annual Human Development Report pp 49 - 76.

Verdurme, A. \& Viaene, J. (2003) Exploring and modelling consumer attitudes towards genetically modified food. Qualitative Market Research: An International Journal, 6 (2), 95 - 110. 